\title{
RISKENESS OF PUBLIC-PRIVATE PARTNERSHIP CONCEPT
}

\author{
Radan Tomek \\ Czech Technical University in Prague, Czech Republic \\ radan.tomek@fsv.cvut.cz
}

\begin{abstract}
Insufficiently functioning infrastructure (whether agricultural, healthcare or transport) is one of the biggest obstacles to general economic development of any economy. The use of the public-private partnership (PPP) concept is very tempting for any government as it represents an extra-budgetary source for the investments' financing. It allows participation of the private sector in various projects ranging from agricultural irrigation to the highway construction. It brings its capital, know-how and experience for financing, construction, operation and maintenance of the service standardly provided by the public sector. This paper lists all standard sources of public infrastructure funding. Considering the differing conditions and possible profitability for various countries, general or project-dedicated government bonds were evaluated and proposed to be the most advantageous extra-budgetary alternative source of funding. In case the public sector has enough credibility for a successful bonds' issuance, it is financially advantageous to use raised money for the capital expenses of the construction project instead of the more expensive private capital's involvement. Two case studies of the currently ongoing PPP projects were used to prove its higher expensiveness in comparison to the economical results of the bonds' issuance. Assessing most important known aspects and problematic issues of the PPP concept and comparing it to the other usual sources and methods of financing, this paper confirms the hypothesis of the PPP's overall higher complexity and expensiveness.
\end{abstract}

Keywords: bonds, cost of capital, highway, infrastructure, PPP.

\section{Introduction}

This research deals with evaluation of the possible use of the public-private partnership (PPP) concept in infrastructure construction and its comparison with the traditional method of implementation by the public sector. By default, all such investment projects are fully financed by the public sector from its budgetary sources. The aim of this research paper is to find and economically evaluate other possible extra-budgetary sources and their feasibility for financing of the large infrastructure projects. Two highway construction projects are used here as a case study, but methodology of this comparison can be applied to all large infrastructure projects. Since this is a discussion of the financial model for large projects in general, its conclusions can be applied across individual sectors of the economy, whether it is a large-scale irrigation project in agriculture or the construction of a wind farm system.

\section{PPP concept}

The issue of infrastructure construction is currently one of the key tasks of most governments of the "new" EU members. The question of its financing is more relevant than ever due to the significant reduction in the flow of subsidies from the European Union after 2023.

The use of the PPP concept is about involving the private sector, its capital and experience in financing, building, operating and maintaining public service and reimbursed by the public sector's interim payments. In the right setting of the PPP model, the following benefits should be achieved: accelerating the development of the infrastructure, transfer/sharing of construction risk [1] (mainly time and cost overruns) [2], no need of investment capital in the construction phase of the project, spread of cost over the longer period of time, private sector know-how and experience are utilized in public projects implementation and in general an increase in the quality of public services.

The main disadvantages include the following: infrastructure or services may be more costly, public sector obligations arising from PPP projects are deferred and may negatively reflect future fiscal indicators of the public sector, the procurement process is longer and demanding higher expertise than traditional procurement and so is very demanding regarding external advisory. Public sector's need to use external, i.e. private consultancy services (for lack of own professional capacities) for the complicated concession dialogue, the concession contract and the financial model bring the risk regarding the true impartiality of these consultants who also have their own financial interest in the project (success fee). The European Investment Bank found 'transaction costs' for PPP deals have 'not received much attention', yet amount to 'well over $10 \%$ of the total project capital value [3]. High, fixed 
transaction costs (legal and advisory fees) on PPP contracts contribute to a trend towards larger, more complex projects and longer procurement timeframes [4].

The World Bank, as of November 2020, lists 139 countries as having passed laws enabling or related to PPPs [5]. As of December 2016, only 92 countries were listed, the trend of growing popularity of the PPP concept and its usage by the national governments is clear. On the other hand, willingness of the private sector to participate in the PPP projects remains stable at 50\% [6]. However, what is significant, in the United Kingdom, the cradle of the PPP concept, trend is totally opposite. Extensive use of the PPP concept (especially in social and health care) exposed its higher financial demands and put the local public services sector into the long-term indebtedness and current cash-flow deficiency. PPPs are hugely unpopular in the UK, with $68 \%$ of respondents in England and $76 \%$ in Scotland saying PPPs should be banned [3].

\section{Research goals}

Resulting research question: Is it economically more advantageous to procure big infrastructural projects, especially highways in the traditional way (via standard design-bid-build project delivery method) or through the PPP model? The aim of the research solution is to confirm the hypothesis of higher financial demands of using the concept of public-private partnership in the current conditions of the EU member countries, or its comparison with the standard method of project delivery (design-bidbuild) using the other possible extra-budgetary sources of financing.

\section{Project financing options}

The standard source for financing public sector projects is primarily the state budget. In general, the following methods of project financing are available [7]:

- budget financing;

- issuance of government bonds;

- subsidies - European Union funds, state funds;
- combination of different options.

- PPP;

- mezzanine loans;

- private capital - credit, rent, leasing;

When considering extra-budgetary sources, two methods of financing can be assessed as the most advantageous in terms of cost. A loan from the European Investment Bank (EIB), with the advantage of the low interest rate, but on the other hand, the disadvantage of limited credit lines. Second possibility is the issuance of government bonds. This option was for the following case studies assessed as more economically advantageous (in general depending on the given country's credit rating) and more dependable because of its proven successful track-record mainly regarding their high demand by the public/investors.

\section{Case study 1 - R1 speedway}

Case study deals with the first big infrastructural project of R1 speedway in neighboring Slovakia, as there is not any other active PPP project in the Czech Republic as of spring 2021 yet. However, the first such highway project will be implemented in the Czech Republic in the near future, the winner of the tender is already known, and the contract has been signed. It is the subject of Case study 2 .

This section of R1 speedway in total length of $51.6 \mathrm{~km}$ from Nitra to Tekovské Nemce + bypass of Banská Bystrica (geographically apart from each other, yet being a subject of one concession) is a pilot PPP project in Slovakia. The case study determines all project costs that the public client pays to the private operator and is discounted for the entire contract period of the project of thirty years. This is then compared with all costs - i.e., construction, operation, maintenance and financial costs that the state highway administration would have in the potential implementation of the project in the standard way using a design-bid-build contract. For comparison purposes, these costs are also discounted by default for the duration of the PPP contract (30 years).

Capital expenditures (CAPEX). The financial model of the R1 expressway shows that the investment costs for the analyzed sections were estimated at EUR 887 million (see Table 1 below). At that time, public sector represented by the National Highway Administration (NDS a.s.) delivered the highway construction with its own design-bid-build contracts for an average of EUR 8-10 million per kilometer [8]. These were highways with a width profile of 26.5 meters, while the R1 is a speedway 
built only in a width profile of 22.5 meters and should therefore be even cheaper. Taking the same investment specification and schedule into account, it would be possible to build the respective sections for EUR 413 million [8]. That suggests that cost of construction seems to be overpriced by the concessionaire. Also, the CAPEX-OPEX ratio does not correspond to the usual composition of two to one third in the whole life-cycle of the project [9]. Overall, the public client therefore paid the concessionaire more than twice the investment costs for this PPP project than he would have to do if securing construction in the traditional way.

Table 1

Cost comparison of PPP and DBB variants (in EUR millions)

\begin{tabular}{|l|c|c|c|}
\hline \multicolumn{1}{|c|}{ Variant } & PPP project & traditional DBB & diff. \\
\hline CAPEX (construction) & 887 & 413 & +474 \\
\hline OPEX (30 yrs of operation and maintenance) & 771 & 771 & 0 \\
\hline Financial and other costs (30 yrs) & 1716 & 434 & $\begin{array}{c}+1 \\
282\end{array}$ \\
\hline \multicolumn{1}{|c|}{ Total } & $\mathbf{3 3 7 4}$ & $\mathbf{1 6 1 8}$ & $\begin{array}{c}\mathbf{+ 1} \\
\mathbf{7 5 6}\end{array}$ \\
\hline
\end{tabular}

Operating expenses (OPEX). The financial model further points out that the costs of operation and maintenance were valued by the concessionaire at EUR 771 million for the whole duration of the contract. The amount of annual costs for operation, maintenance and overhead of adjacent sections, which is maintained by NDS, is about half. These sections are of similar length, but older and with a larger number of intersections [8], and so it can be assumed that the real maintenance cost of the analyzed newly built section would be lower. However, unlike firmly agreed OPEXs under PPP contract, these future costs of the public administration can only be estimated. On the other hand, according to the contract, the concessionaire is forced to adhere to a higher standard of maintenance quality than state organizations [10]. For these reasons, and also because the difference between the private and public sectors in total represents a low percentage of the total price, in order to better compare the two methods of project implementation we can use the amount from the concession contract for the potential OPEX of the National Highway Administration as well.

Cost of funding. The financial model of the concessionaire shows that the price, i.e. the interest rate of the loan for which it secured the sources of project financing, was $10.27 \%$ p.a. It can be generally considered to be relatively high even for the private sector borrower. Especially considering the capital power of the concessionaire (Eurovia, member of the Vinci Group, long-term top 10 highest-grossing global contractor). At the same time, the concessionaire cannot be suspected of increasing this rate in any way in order to make the project more expensive, as it is purely at its own expense and is therefore always at the lowest possible amount it can negotiate with the financing institutions. In the following paragraph, an evaluation of the amount of costs that a state investor would have with the analyzed project is performed. For the sake of comparability, it is necessary to consider a situation where the state does not have its own funds and must therefore borrow them.

The standard form of government borrowing are the bonds (currently accounting for $86 \%$ of the country debt). They are financially advantageous for the state and are therefore considered for this analysis as the only probable source of external financing. Average interest rate on government bonds issued up to year 2009 ranged from $1.73 \%$ p.a. up to $5.19 \%$ p.a. [8]. As the average maturity of PPP project financing of R1 speedway is more than 15 years, it is correct to compare its price with government bonds with the longest maturities, through which the state borrowed back then, usually at prices above $4.5 \%$. [8]. International agencies' ratings prove Slovak advantageous low-interest rate options in 2009 (Standard \& Poor's: A +, Moody's: A1, Fitch: A + ).

The fact that concessionaire's project financing costs are twice as high is crucial for the overall assessment of the feasibility of the PPP concept for the low-risk projects. As mentioned in the previous chapter, private sector participation balances its relative financial disadvantage by taking on most of the project's risk. However, risk does not reach such high values on the project and the involvement of the private sector therefore remains enormously overpriced. In addition, it represents a financial burden for thirty years (including indexation to inflation). 
Economic comparison of selected methods of financing. Table 2 below compares the two variants and what costs they represent for the public sector on an annual basis and in total. The first option is a really implemented PPP agreement. The second is a hypothetical variant in which the public client delivers the project on its own and through the standard design-bid-build project delivery method - with the only exception against the standard - using extra budgetary financing.

Table 2

Costs' breakdown - private vs. public sector project delivery (EUR million)

\begin{tabular}{|c|c|c|c|c|}
\hline \multirow{2}{*}{ Year } & \multicolumn{2}{|c|}{ PPP } & \multicolumn{2}{c|}{ DBB with gov.bonds } \\
\cline { 2 - 5 } & Annual & $\begin{array}{c}\text { Cumulative } \\
\text { total }\end{array}$ & Annual & $\begin{array}{c}\text { Cumulative } \\
\text { total }\end{array}$ \\
\hline 2011 & 91.0 & 91.0 & $413+40.16$ & 453.16 \\
\hline 2012 & 92.3 & 183.3 & 40.16 & 493.32 \\
\hline$\ldots$ & 100.4 & 765.2 & 40.16 & 734.28 \\
\hline 2018 & 10.3 & 40.16 & $\mathbf{1 6 1 7 . 8}$ \\
\hline 2040 & 137.0 & $\mathbf{3 3 7 4 . 3}$ &
\end{tabular}

Within the actually implemented PPP concept, annual installments represent payments for the availability of the service (the possibility to use speedway in the capacity and quality defined in the concession contract). The state is obliged to pay these installments for the entire period of validity of the contract. These payments are increased according to inflation (indexed in the contract). The values given in the table below are indicative (the values of the payment for availability will vary in individual years according to the quality of the concessionaire's performance). Their averaging was performed in the interest of clarity and illustration of the overall course of the financial intensity of the contract for the public sector. However, their total amount corresponds to a real total of EUR 3.4 billion over the entire 30 years of the contract.

DBB column shows the potential cost to the public sector in case the R1 speedway project would have been implemented in the form of design-bid-build using the dedicated government bonds. Their value is considered to be a total of EUR 413 million, which was retrospectively determined by the Slovakian government in 2012 as necessary for the implementation of the project if the PPP approach was not used (see CAPEX paragraph above). To be comparable with the PPP concept, the maturity of the bonds is also considered to be 30 years. In the first year, for the sake of clarity, capital expenditures in the full amount of EUR 413 million are included (instead of their inclusion in the previous two years of construction), but these are secured for the public sector from issued bonds and therefore do not come from budgetary sources. In all years, the costs of bond repayment and all operational and maintenance expenses are evenly considered (for their breakdown see Table 3 below). Table 2 also shows the breakeven point in the seventh year (year 2018), in which the issuance of bonds hypothetically becomes more advantageous against the PPP's annual availability payments.

\section{Annual costs' breakdown under DBB - years 2-30 (EUR million)}

Table 3

\begin{tabular}{|c|c|}
\hline Repayment of premium & 13.77 \\
\hline Installment at 5\% interest & 0.69 \\
\hline OPEX & 25.7 \\
\hline Total & $\mathbf{4 0 . 1 6}$ \\
\hline
\end{tabular}

The value of EUR 40.16 million represents the total annual cost to the public sector (after completion of construction) of the potential implementation of the project on its own and is thus fully comparable to the cost of the concessionaire and everything contained in the annual availability payment. It is half cheaper to provide for all the same services.

\section{Case Study 1: Results and Discussion}

An economic comparison between public-private partnership type of project delivery and the traditional design-bid-build approach with an extra-budgetary source of financing was carried out. Its main purpose was to find out whether in the situation of lack of public sector's funding the PPP concept 
is economically advantageous, or whether it pays off for the public sector to find other ways to finance the project (mainly its construction as it is the most demanding phase of the project and the main reason and benefit of involving the private capital in the low-risk type of projects). Government bonds' issuance was chosen to be the extra-budgetary source of funds based on their highest economic advantageousness and the proven successful track-record mainly regarding their demand.

Prompt income from the successful government bonds' issuance plus distributing their repayment over the whole duration of the project does offset two of the main advantages of private sector involvement. Other main advantage of the PPP concept, which is the transfer of risk from the public to the private sector, does not present significant value in the analyzed project. Mainly, it should be about the demand for public service, i.e. the amount of traffic on privately operated sections. However, according to the contract, this is borne by the public sector and the concessionaire is remunerated only on the basis of the availability and quality of the service, not by its real usage. The other most significant risks in the construction of infrastructure are the readiness of land and property settlement, or all the necessary permits, especially environmental ones. These were also on the side of the contracting authority.

Based on the analyzed data, it was proven that the PPP project, with a total price of more than EUR 3.4 billion, was not the most economically appropriate solution. Its total price is 2.1 times higher than its implementation would be in a relatively traditional and standard way - through a design-bid-build project delivery scheme combined with the issuance of government funds used for the capital expenses of the project. The risks of the project taken over by the private sector were assessed as low and therefore do not outweigh the high cost of the project. There are two other important reasons why governments in general still prefer PPP projects. First, the state does not seemingly incur any construction expenditures, so the state budget is not burdened. Secondly, the annual installment of PPP projects is not reflected in the public debt, because it is allowed by Eurostat and is therefore politically very advantageous. However, this creates a hidden debt that will burden the country throughout the repayment period [11].

\section{Case study 2 - D4 highway}

Case study 2 analyses the currently ongoing pilot project in the Czech Republic for the completion of the D4 highway, section Háje-Mirotice. The contract with the concessionaire was recently signed and is scheduled to be operational in 2024. The concessionaire will first build 32 kilometers of highway and subsequently will operate the communication for the next 25 years, including the already existing 16 kilometers. The state's direct liabilities together represent approximately EUR 1150 million [12]. However, the price will be gradually increased by other influences, such as inflation or the development of the CZK exchange rate. The financial model is not yet publicly available, the only information available is the total price of the project (see above) and the interest rate of $4 \%$, at which the concessionaire borrows capital.

\section{Case study 2: Results and Discussion}

The usual interest rate for which the Czech Government borrows is $1-2 \%$, as the credit rating of the Czech Republic is currently at AA level. Although not knowing the cost for operation and maintenance of the concessionaire, comparing his borrowing cost with the public sector capabilities, we can conclude that the aggregate price of the project is EUR 170 million higher. The second largest benefit of private sector involvement, i.e. transferring significant risks to concessionaires does not balance higher financial demands. The risks on the project are unusually low as the state has purchased land, has a valid building permit and a finished design, and building a highway by standard procedure is not complicated. Quite often the political motivation to pursue the project via PPP is stronger than arguments about its economic disadvantage.

\section{Conclusions}

1. Forming the public-private partnership in the low-risk type of infrastructure construction projects does not pay off for the public sector which is lacking funds for the investment (especially governments), but has relatively solid credit rating. The difference in cost of capital in the analyzed case studies was the governmental 4,5\% versus private sector's $10.27 \%$ p.a. in Slovakia and $1 \%$ 
versus $4 \%$ p.a. in the Czech Republic. In case the public sector has enough credibility for successful bonds' issuance (either general or project-dedicated), it is financially advantageous to use the raised money for the capital expenses of the construction project instead of the more expensive private capital involvement.

2. Assuming that the public sector has relatively solid credit rating, successful government project dedicated bonds' issuance offsets two of the main advantages of the private sector involvement. Firstly, provided the investment capital needed for the construction phase is made up for by the prompt income from the bond's proceeds. Secondly, distribution of installments of investment costs over the long period of time is replaced by distributing bond's repayment over the whole duration of the project.

3. Private sector involvement pays off for the government only when the value of the project risk carried by the private contractor outweighs his higher expensiveness (versus the governmental project delivery). As the Case study 1 shows, Concessionaire's project financing costs might be double to those of the Government for the low-risk projects. Case study 2 then highlights this conclusion by project financing costs being four times higher, resulting in an unnecessary increase in the total cost of the project by 15\% (approx. EUR 170 million).

\section{References}

[1] Osei-Kyei R., Chan A.P.C. "Review of studies on the Critical Success Factors for Public-Private Partnership (PPP) projects from 1990 to 2013”. International Journal of Project Management, 2015, Volume 33, Issue 6, 1344 p., ISSN 0263-7863

[2] Boussabaine A. Cost Planning of PFI and PPP Building Projects, Routledge, 2016, ISBN 9781138966840, $16 \mathrm{p}$.

[3] Benjamin J., Jones T. "The UK's PPPs disaster - Lessons on private finance for the rest of the world". Jubilee Debt Campaign. 2017, 3 p., 2 p., [online] [15.03.2021]. Available at: https://jubileedebt.org.uk/report/uks-ppps-disaster-lessons-private-finance-rest-world

[4] HM Treasury: National Audit Office (UK): The choice of finance for capital investment, 2015, Figure 7 and 17. [online] [15.03.2021]. Available at: https://www.nao.org.uk/wpcontent/uploads/2015/03/The-choice-of-finance-for-capital-investment.pdf

[5] The World Bank "Public-Private Partnerships Laws/Concession Laws". [online] [15.03.2021]. Available at: https://ppp.worldbank.org/public-private-partnership/legislation-regulation/laws/pppand-concession-laws\#examples

[6] Xiaosu Ye et al. "Empirical Analysis of Firms' Willingness to Participate in Infrastructure PPP Projects". Journal of Construction Engineering and Management. 2018, 8 p., 144. 04017092. 10.1061/(ASCE)CO.1943-7862.0001404.

[7] Asociace PPP "PPP versus Veřejná zakázka" (PPP versus Public Procurement), internal material of the organisation associating legal entities and independent experts, 2008 (In Czech)

[8] Office of the Government of the Slovak Republic "Zhodnotenie stavu jestvujúcich PPP projektov s ciel'om zefektívnenia d'alšej výstavby dopravnej infraštruktúry formou PPP" (Evaluation of the status of existing PPP projects with the aim of streamlining the further construction of transport infrastructure in the form of PPP). [online] [15.3.2021]. Available at: https://rokovania.gov.sk/RVL/Material/8312/1 (In Slovak)

[9] Tomek R. "Improving Effectiveness of Public Spending on Transport Infrastructure". Periodica Polytechnica Architecture, 2017, pp. 65-71. DOI: 10.3311/PPar.11037

[10] Anastasopoulos P.Ch., Haddock J.E., Peeta S. "Cost Overrun in Public-Private Partnerships: Toward Sustainable Highway Maintenance and Rehabilitation". Journal of Construction Engineering and Management, American Society of Civil Engineers, Volume 140 Issue 6 - June 2014, DOI: 10.1061/(ASCE)CO.1943-7862.0000854

[11] Cepparulo A, Eusepi G, Giuriato L. "Public-Private Partnership and fiscal illusion: A systematic review". Journal of Infrastructure, Policy and Development; 2019, 3(2): pp. 288309. DOI: $10.24294 /$ jipd.v3i2.1157

[12] Ministry of Transport of the Czech Republic Press release of 6.2.2021. [online] [15.03.2021]. Available at: https://www.mdcr.cz/Media/Media-a-tiskove-zpravy/Poslanci-souhlasi-s-dostavboua-udrzbou-dalnice-D4?returl =/Media/Media-a-tiskove-zpravy $($ In Czech) 